\title{
Empowerment of Fishing Communities in the Management of the Results of the Sea in Indonesia
}

\author{
Andi Sulfati, Patta Rapanna, Nurlaely Razak \\ (Lecturer at High School Economics Makassar (Stiem) Bongaya), South Sulawesi, Indonesia
}

\begin{abstract}
This type of qualitative research phenomenological approach, the results showed that the potential of the sea is very important in the people's economy, raise the potential has not managed professionally, this is due to the fishing potential has not been optimal, so the concept of empowerment and of Government policy in favour of fishermen is a real solution in making changes and increased progress in various sectors of its main on community empowerment coastal fishing sector.
\end{abstract}

Keywords:- Empowerment, strategy, the fisherman, the sea, the potential.

\section{INTRODUCTION}

\section{A. Background}

Indonesia is the largest archipelago in the world with a sea area of $2 / 3 \mathrm{~m} 2$ total area of its territory. Based on the Declaration of 1957, the sea terminal building QUR'ANIC PLURALITY is approximately 3.1 million square kilometers. the area grew SO vast sea of additional Exclusive economic zone (EEZ) of 2.7 million square kilometers, into a total of about 5.8 million square kilometers. Indonesia gets the sovereign rights over the natural resources in the EEZ as far as 200 miles from the base of the Archipelago or straight up to the limit of the ' continental margin'According to, Oentoro Surya (14/6 2009), that the nation of Indonesia should be able to succeed in the field of marine. The potential of our wonderful sea, but since many circles that still underestimate the against the enormous natural wealth, the management of marine Indonesia not optimal results. The sea of Indonesia, this immense, inordinate economic potential that can be developed, such as for the purpose of shipping, ports, fisheries, shipping, tourism, and mining, which of course would open up new jobs. Given the potential of marine resources and fisheries owned its utilization is still low, then attempts to grow the business activities of fishing in the fishery in regional revenue increase still had enough opportunities large.

Indonesia is one of the countries that has a wealth of natural resources shall, however, not least the potential of the natural resources that have not been maintained and is touched by technology. One of them is the potential of waters, therefore development policies on the fishery essentially leads to welfare welfare, capacity, independence and access to fishing communities in the development process through improved the quality and quantity of production, distributi and diversity of fisheries yield, in which the national development goals of a just and prosperous, to achieve those goals need to be developed and maintained the resources available. Indonesia's waters is the widest area of the Republic of Indonesia to the waters where freshwater is estimated to be \pm 55 million acres comprising the River area of 11.95 million hectares, of the natural and artificial lake covering an area of

2.1 million hectares where all contains waters of various types of fish, aquatic plants, aquatic animals and so on, where the waters and its benefits can be made as authorized capital of development in an effort to increase well-being and prosperity for all the people. Fisheries sector development more emphasized on developing people's fisheries to improve the nutritional quality of the community and create job opportunities in increasing income and livelihood of fishermen, where in its entirety is directed on increasing its contribution in terms of tackling the national issues, namely:

(1) the availability of animal protein ingredients, (2) increase in foreign exchange, (3) create jobs, (4) increase the income and welfare of fishermen.

In traverse the policy improvements fisheries in these waters and coastal sea fisheries are given top priority, given some low-income residents make a living in these waters, as a result of such policies since the years 1968 - 2001 results throughout Indonesia fishery has increased rapidly, in a period of increased marine fisheries yield the 723,000 tons in 1968 became 8,968,000 tons the year 2001 (BPS, 2002). When we observe further that most of society Indonesia living in rural areas of $80 \%$ of the entire population, most of whom are poor farmers and fishermen who still think and work in ways that are very simple, a situation which still characterizes the traditional society, the nature of this traditional education backed by the relatively low and hang on to his life from the agricultural sector in the sub systems. Whether as farmers or fishermen who are low income, this means that the work as farmers or fishermen are already so closely and can not be separated in the process of their activities to the fulfillment of the needs of everyday life, because it work as farmers or fishermen need to get attention to the improvement in standard of living. In the socio-economic life not only concerning a change in the rate of improvement of living conditions, but also upholding the Division-Division of goodness. In the implementation of socio-economic life there are several factors that affect the level of community life such as culture, social facilities and infrastructure as well as population. On the one hand the economic social life in his not entirely tackling the lameness-social lameness. This indicates a process that has a diversity of needs, which in fact only a 
fraction of the community concerned to alleviate the burden of suffering fellow human beings.

\section{B. Formulation of the Problem}

How does the empowerment of fishing communities in the management of the results of the sea in Indonesia.

\section{A REVIEW OF THE LITERATURE}

\section{A. Community Empowerment}

Empowerment efforts are in fact power or increased helpless. Community empowerment can be interpreted as an effort to standalone the public to actively participate in all aspects of development. Self-reliance is open means being able to live alone but independent in decision-making, i.e. has the ability to choose and courage rejected all forms of aid and cooperation or unprofitable.

With such an understanding, empowerment can be defined as the process of planned to improve/upgrade the scale of the utility of the object to be powered. Therefore community empowerment is an effort to continuously improve the dignity and the dignity of the lower layers of society who were not able to escape from the trap of poverty and underdevelopment. In everyday understanding, community empowerment is always the connotations as lower class community empowerment (grassroots) that are generally assessed not defenceless.

Mainly grass root community participation in development during the past 50 years it is something artificial, as the slogan, engineered and forced. With the implementation of the pattern then place scant public participation. In the late 1990 's, the community empowerment program in lieu of coaching programs the community started to have a place because the empirical evidence and experience in many countries. Empowerment program into the new mainstream in development and promoting developed by non-governmental organizations (NGOs). The program is the involvement of community empowerment and increased participation of the community, that community-based and because it rises in accordance with their needs and aspirations, the program originated from the bottom (bottom up planning) which means community who proposed it, as well as a program of the nonprofit advocacy because the role of an outsider only as accompany and provide an alternative solution to the community.

\section{B. Public Policy}

Public policy often made without much dependence on economic reasoning. Economists often do not realize what is happening in the world of public affairs. As a result, both the quality of public decision-making and the role that economists play in it less than optimal (in Alicia h. Munnell, 1992). Public policy is something that is dynamic and complex instead of something stiff and dominated by the sheer formal power holders, but public policy back to the basic meaning of
ISSN No:-2456-2165

democratic i.e. the policy of, by and for the public (the people).

Since the inception of the Law Number 32 year 2004 about local government and Law Number 33 year 2004, enhanced with the process of decentralization legislation requires power distributed to the lower layers of society. According to Sudantoko the implementation of promising a lot of things for the benefit and welfare of the public life at the local level.

According to the Regional Autonomy Law number 22 year 1999 and Act No. 25 of the year 1999, the Government and people in the area are welcome to take care of his household own responsibly. The Central Government is not controlled with full, but only to the extent of giving direction, monitor, monitor and evaluate the implementation of regional autonomy. Thus every national policy should be implemented by the local government. Implementation is not only in the form of interpreting the policy in a technical manual, but also having regard to various factors that affected it.

Michael e. Porter in Susy Susilawati (2007) tells us that competitive advantage from each State is determined by how capable the country was able to create an environment that fosters the competitiveness of every actor in it. In the context of global competition, then the task of the public sector is building an environment that allows each of the principals of development able to develop themselves into the perpetratorperpetrators are competitive. This environment can only be effectively created by the existence of public policy. Therefore, the best public policy is the policy that encourages every citizen to build community power competitiveness respectively and not more and plunges into a pattern of dependency.

While Suharto (2007) in Susy Susilawati (2007) stated that the policy (policy) at its core is the decisions or actions which directly regulate the management and distribution of natural resources, financial, and a human being for the sake of public interest, namely the people's lot, population, society or citizens. The policy in fact is the result of a synergy of compromise, or even competition among the various ideas, theories, ideology, and representing the interests of the political system of a country. Other definitions similarly expressed Nugroho (2008) in Susy Susilawati (2007), that public policy is a decision that made the State Government, especially as the realization of the objectives of the strategy of the State concerned.

From the various definitions can be summarised the existence of three dimensional public policy as expressed in Suharto and Davis Bridgeman (2007) (Susy Susilawati, 2007) i.e. public policy as a destination, the choice of a legal action, and as a hypothesis. In the context of public policy, in addition to the Government as a decision maker, there are also policy stakeholders. 
The stakeholders here are individuals, groups, or institutions having an interest against a policy. This policy can be a stakeholder of the actors involved in the formulation and implementation of policy, the beneficiaries as well as victims harmed by a public policy. There are three groups of key stakeholders i.e., primary, and secondary stakeholders (Suharto, 2007 in Yuli dkk, 2012). While the public policy process itself consists of three stages, namely the formulation, implementation, and evaluation (in Yuli dkk, 2012).

\section{Public policy Transparency}

Transparency is a principle that guarantees access or freedom for everyone to obtain information about the Organization of the Government, that is, information about the process of making policy, and the implementation, as well as the results achieved. Assumptions can be formulated, more transparent public policy, which in this case is a GRANT then supervision is performed by the Board will be increased because the society is also involved in overseeing public policies (Yulinda and Lilik Rudianto, Earn in 2012).

Implementation of policies is a process implementing the policy decisions made by the individual/group or Government officials as well as private in order to achievement of the objectives outlined in the policy decisions that will affect the final results of a policy. With regard to the success of the implementation of the policy, Edward III (in Iskandar, 2012:90) suggests four factors that affect the implementation of the same policies or whether a policy is successful (1) communication (2) resources (3) Dispositions/Attitudes (4) bureaucratic structure (Supianto, 2012).

\section{RESEARCH METHODS}

Qualitative research approach through kind of Phenomenology.

\section{A. Marine Resources Potential:-}

Community-based marine resource management and knowledge of this technology is not something new for the people of Indonesia. Since long ago, local communities in Indonesia have a mechanism and rules work as of the rules of life in society in managing natural resources including marine resources. Unwritten law is not only the economic aspects of governing the utilization of marine resources, but also covers the aspects of preservation of the environment and dispute resolution (Weinstock 1983; Dove 1986, 1990, 1993; Ellen 1985; Thorburn 2000). One of the driving factors of Rudy catapult concept and true opinion Weinstock (1983) is avoiding friction up-bottom (Government-society) that in fact still holds an unwritten Law or custom that sometimes clashed with the regulation or Government policy. However, that does not mean the Government hands-off. In this concept the Government is expected to be a facilitator, and the authorities are required to better understand the circumstances and lead local people to participate equally in an effort to play an active role managing marine resources, so it is not going negative
ISSN No:-2456-2165

impact for all such massive exploitation without controls that would be a loss for the community itself.

The idea was started by exposing the potential and the role of marine resources in Indonesia. The role of marine resources can be views from several aspects, namely:

- Economic aspects of marine resources,

- Ecological Aspect of marine resources.

- Aspects of Defense and security, and

- Educational Aspect.

Marine resource economics is economic activity is conducted in the coastal areas and oceans or economic activities that use the coastal and ocean resources or economic activities that support the implementation of economic activities in the region the coast and the sea. Thus the scope of marine resource-based economic activities is very wide and varied, including capture fisheries and aquaculture sector. fishery products processing industry and biotechnology, marine and coastal tourism, mining and energy, marine transportation, industrial ship, the sea and the beaches, small islands, and the utilization of valuable objects. From a wide range of marine resource-based economic activities that are very broad and diverse, in fact the economic potential that can be produced and donated for.

The Government has prepared tools to manage marine resources, but the community hasn't been able to exploit it optimally and have not tergali optimally in support of economic development of the nation of Indonesia. In Indonesia recorded a high marine biodiversity. Found about 2500 species of fish, 253 of these types include type of ornamental fish, and 132 types of fish worth economy.

The role of the community is Educated in the management of Marine Resources. Throughout the history of human civilization, the well-educated who become the engineer and make some locomotives so it could be now. In various fields, well-educated people always expected and demanded to be able to lead the people towards a new society, to the most ideal stage for the welfare and prosperity of its people that is wrapped with justice. Just as civilizations, in dealing with leaks-leaks in managing marine resources, it requires an active role of the community is educated. How not, with more knowledge, in accordance with his knowledge base then it would be very possible for people trained to carry and lead the society toward the ideal conditions for the people. With the potential-potential that hasn't been export, then the role of the educated community will be indispensable in order to seek out and exploit the potential-potential that has not been well managed.

\section{B. The potential and the spread of Marine Resources in Indonesia}

Potential Fisheries and Marine Resources Distribution in Indonesia Aquaculture the marine fisheries resources is one of the potential resources of the sea in Indonesia, which has been 
historically exploited population. The sea of Indonesia has a huge potential for sustainable, i.e. 6.4 million tonnes year. What is meant by sustainable potential is the potential of catching fish that still allows the fish to do regenerate until the number of fish caught is not reducing fish populations. Based on international rules, the amount of the catch is allowed is $80 \%$ of the potential of the sustainable or about 5.12 million tons per year. In fact, the number of catches in Indonesia have yet to reach that number. This means there are still opportunities to increase the number of catches are permitted. If compared the distribution of potential fish, visible distinction in General between the Western and Eastern parts of Indonesia. In the western part of Indonesia with an average depth of 75 meters of the sea, a type of fish that many small pelagic fish are found. Somewhat different conditions found in Eastern Indonesia region with average depths of the sea reaches $4,000 \mathrm{~m}$ In the eastern Indonesia region, many large pelagic fish are found such as skipjack and tuna. In addition to the available fish in the ocean, the population of Indonesia are also many that do aquaculture, especially in coastal areas. On the North coast of Java Island, many societies that developing aquaculture businesses by using the Causeway. The types of fish that breed there is fish milkfish and shrimps. In addition to fish the sea wealth, Indonesia is also in the coastal areas in the form of mangrove forests, seagrass, seagrass meadow, and coral reefs. Indonesia has more than 13 thousand islands so very long coastline. The shoreline length is Indonesia reached $81,000 \mathrm{~km}$, this size is the length of the second longest Beach in the world after Canada. Therefore, the potential of natural resources in the coastal areas is very important for Indonesia. Not wrong if the Government under the administration of the President of the maritime development focusing the Jokowi Indonesia. Our natural wealth in the form of fish and even many taken by unscrupulous persons from other countries in the form of the practice of stealing fish or illegal fishing. There are some areas of Indonesia's waters are prone to illegal fishing activities. The most prone areas with Sea fish is theft practices Arafuru (Papua) in eastern Indonesia waters.

\section{The Mangrove}

Forests of Mangrove Forests of mangrove forests (mangroves) is a type of forest that are in tidal areas of sea water. When the tide is inundated, mangrove forests by the sea water, whereas at low tide, mangrove forests are free from pools of sea water. Generally the mangrove forests thrive in the sheltered Beach, estuary, or lagoon. Plants that live in the mangrove forest habitat are resistant to salts contained in the water of the sea. There are two function of mangrove forests as potential marine resources in Indonesia that is ecological and economical functions. Ecological functions of mangrove forests as habitat (a place of living) sea animal for shelter, feed, and breed. Other ecological functions of mangrove forests is to protect the coast from sea water abrasion. Economical function of mangrove forests in the form of economic value of wood, trees and creatures living in it. Usually the population utilizing wood as firewood or charcoal makers. Mangrove wood can also be used as material of paper
ISSN No:-2456-2165

maker. In addition to lumber, mangrove forests are also occupied by various kinds of fauna which is worth it economically, for example, shrimp and other species of fish that breed in the region. Where are the distribution of mangrove forests in Indonesia? Mangrove forest spread across the West coast of Sumatra Island, some parts exist on the North coast of Java Island, along the coast of the island of Borneo, Sulawesi Coast, Coast south of New Guinea, and some other smaller islands. The number of mangrove forests in Indonesia to reach 3,716,000 ha (data from UNESCO). Mangrove forests Indonesia does not spread evenly. The largest extensive mangrove forests located on the island of New Guinea which reached 3.7 million ha. Next is Borneo (165 thousand ha), Sumatra (417 thousand ha), Sulawesi (53 thousand ha), Java (34.4 thousand ha), Bali and Nusa Tenggara (3.7 ha).

\section{Coral reefs}

Coral reefs are reefs (Cretaceous sedimentary rocks in the sea) are formed from limestone which is mostly produced from coral (animal that produces lime for her body frame). If thousands of corals form colonies, coral-the coral reefs will form. As an island nation, Indonesia is a country that has the largest coral reef in the world. Extensive coral reefs of Indonesia reached 284.3 thousand $\mathrm{km} 2$ or equivalent to $18 \%$ of the coral reefs that exist around the world. The wealth of Indonesia's coral reefs not only of the vastness, but also the biodiversity that exists in it. Biodiversity of coral reefs as a potential sea resources in Indonesia is also the highest in the world. In it there are 2,500 species of fish, 2,500 types of molluscs, 1,500 types of crustaceans, and 590 species of coral. Why coral reefs are found in the territory of Indonesia? Coral reefs can grow well on the temperature of the sea waters between $290-210 \mathrm{c}$. On temperature is larger or smaller than that, the growth of coral reefs to be less good. Since Indonesia is located in tropical and warm waters temperature, it's reasonable if the coral reefs found in Indonesia. The growth of coral reefs would also be good on the conditions of the water crystal clear and shallow. The depth of water is good for the growth of coral reefs are no more than 18 meters. If the depth is greater than, the growth of coral reefs would also be less good. In addition to these requirements, coral reefs also require the salinity (salt content of seawater). Therefore, it is difficult living coral reefs around the estuary of the river due to its decreased due to water levels of salt mixed water of the River to the sea. Coral reefs marine resources why coral reefs are protected from damage by mandatory? The coral reef has many benefits, good benefits that are economical, ecological, economic and social. As for an overview of the benefits of coral reefs are as follows. Economic benefits: as a source of food, medicine, and marine attractions. Ecological benefits: reduce crashing waves Beach which can result in the occurrence of abrasion. Benefit analysis: the fisheries as a source of income which can improve the fishermen. Coral reefs can also be a tourist attraction which can increase the income of the population from tourism activities. Coral reefs are found in the central regions of Indonesia such as Sulawesi, 
Bali, Lombok, and Papua. The concentration of coral reefs are also found in the Riau Islands, the West Coast and the Western tip of Sumatra.

\section{E. Seaweed}

As a maritime country, Indonesia has a huge potential in utilizing various types of seaweed that live in its waters. Various types of seaweed has been known to have good benefits as a maker of gelatin, a alginat, nor yeast. Various types of seaweed has been successfully cultivated in various regions of Indonesia.

\section{F. Sea water}

Sea as a means of transportation and Freight

The sea can be used as line traffic transport ships from the island to other islands so that the flow of freight and passenger transport can take place properly. In addition, the relationship of reciprocity between the countries that one with other countries, both in the field of social, economic, political, and others.

- The sea as a source of Energy.

- Ocean currents can lighten the power boat, for the presence of ocean currents the boat can glide with no need to spend a lot of energy. In addition, the motion of the tides sea water can also be utilized for power generation.

- Sea Fishing Area As.

- Animal resources from the sea can give life to the population. The animal resources in the form of various types of fish, scallops, crab, prawns, pearls, and others. The results of fish in Indonesia per year \pm 1.7 tons. The types of fish caught, among others, COB, tengiri, catch small whales, and tuna. Sea fishing areas are in the Shoal Sahul Shoal, Sunda, Java Sea, Bali Strait, and the Strait of Malacca. Regional fisheries in Indonesia the largest contained in Exhibit Siapiapi, Riau, Indonesia.

- The sea as a Recreation/Tourism.

- The area of the sea with its beautiful beaches and the relief much visited by tourists. Sights of the sea in Indonesia, namely the famous Beach of Pangandaran (West Java), the Moluccas, Parangtritis, Banda Sea (Yogyakarta), Alap (Jakarta), and others.

- The sea as a place of defence and security.

- The utilization of the sea as a place of defence and security especially for countries that are surrounded by the seas or the country's maritime interests.

- Sea as Climate Control.

\section{G. The coastal communities and management of seafood}

According to Horton et. Al. (1991) defines society as a group of humans that are relatively independent, quite a long life together, a certain territory inhabited, have the same culture, and does most of its activities in the group. Ralph Linton (1956), in Sitorus et. Al. (1998), defines society as a group of human beings who have lived and worked together long enough so that they can organize and think of themselves as a single entity with social boundaries are clearly
ISSN No:-2456-2165

formulated. While Soejono Soekanto (1990) detailing the elements of society as follows:

- Human beings live together.

- Mixed in a long time.

- Conscious as a whole.

- Aware as a system of living together.

Coastal communities are groups of people who live in the coastal region and the source of life economy depending directly on the utilization of marine and coastal resources; They consist of the owner fishers, fish farmers, fishermen, laborers and other marine organisms, fish processors, fish traders, suppliers of means of production factors in fisheries. In the field of non fisheries, coastal communities can consist of seller, seller's tourism services transportation services, as well as other groups that utilize the resources of marine and coastal non biodiversity to support life.

Fishermen, fish farmers, and traders is a group of coastal communities who directly cultivates and harnesses the resources of fish through capture and aquaculture activities. This group also dominates the settlement in the coastal areas on islands big and small in Indonesia (Nikijuluw, 2003). Coastal communities some became small and medium scale entrepreneurs, but more of them are subsystems, undergoing its economic activities and efforts to raise a family by yourself, with a scale so small that the results only enough to meet the short term needs.

The fishing effort of the sides, the Group of poor coastal communities consist of household fisheries which catch fish without a boat, using a boat without a motor, a motor boat and outboard. The scale of effort like this, fishermen only catch fish in the area near the beach. In some cases, fishermen can work together or partnering with larger companies, so they can go catch fish farther from shore (Nikijuluw, 2003). However, the increase in earnings from the results of this cooperation are not much meaning because the number of household members is great cause the amount of income they have not been sufficient to cover the needs of everyday life.

Poverty as indicators failed to coastal communities is due to three things, namely the structural poverty, cultural super structural, and (Nikijuluw, 2003).

- Poverty is a structural socio-economic structure of society, the availability of incentives or disincentives to development, the availability of facilities development, availability of technology, and the availability of resources for development, in particular of natural resources.

- Poverty super structural poverty is caused because the macro policy variables not or less in favour of the construction of fishing communities.

- Cultural Poverty poverty is caused because the variables inherent, inherent, and became a particular lifestyle that caused the individual concerned is difficult out of poverty 
because of these factors unconscious or not known by the individual concerned.

The poverty of the coastal communities, especially fishermen, more due to factors related socio-economic characteristics of the resources and the technology used. Smith (1979) and Anderson (1979) concluded that the fisheries assets that strength is the main reason why the fishermen still struggled with poverty and nothing seems their efforts to break out of the poverty of that. Stiffness of the assets is the nature of the fisheries assets difficult to liquidated or altered form and function to be used for other interests. As a result, at the time the assets are low productivity, fishermen cannot afford to over the function or liquidate the assets. Therefore, although the low productivity, fishermen still do the actual fishing operations are no longer economically efficient.

Based on the concept of community development which emphasizes on empowering then formulated goals of empowerment coastal communities, particularly fishermen and fish farmers who live in the coastal area of the island is small and large, are as follows:

- The availability and satisfy basic human needs which consists of clothing, food, Board, medical care, and education.

- The availability of infrastructure and means of production locally that lets the public can acquire it with cheap price and good quality.

- Increasing the role of the institutional community as a container of collective action (collective action) to achieve the goals of the individual.

- Creation of productive economic activities in areas that have traits based on local resources (resource-based), have a clear market (market-based), is conducted on an ongoing basis having regard to the capacity of the resource (environmental-based), owned and implemented as well as the impact to the local community (local society-based), and using appropriate advanced technology derived from the process of assessment and research (scientific-based).

- The creation of a relationship of transport and communication as the basis or foundation of economic relations between the coastal regions and between coastal and inland.

- Materialize Indonesia economic structure based on economic activity in the coastal areas and the sea as a form of utilization and utilization of natural resources of the sea.

\section{$>$ Community empowerment approach to Coastal}

Less helpless coastal communities among other things caused by limitations in their mastery of the science, technology, and institutional venture capital. There are at least five coastal community empowerment approach has just been implemented. With a fifth of this approach does not mean that another approach does not exist. The fifth approach is implemented by considering in earnest aspirations, desires, needs, income, and the potential resources that belong to the
ISSN No:-2456-2165

community. A short blurb about a fifth of this program is as follows:

\section{A. Develop Alternative Livelihoods}

First, the development of alternative livelihoods is implemented with the consideration that the coastal resources in General and specifically the capture fisheries have been subjected to pressure and degradation. Empirical data shows that it is too many fishermen who concentrate in specific waters. In fact nationally, seems to be the number of fishermen has also been exaggerated. The potential of marine fish is available, if it is true, the estimation have been unable to be used as the mainstay for the improvement of well-being. If the number of fish allowed to be taken exactly arrested everything then a rough calculation based on average, fishermen are very difficult to prosper.

\section{B. Access to capital}

The second element of the strategy is the development of fishermen empowerment access to capital. This strategy is very important because it is essentially the current coastal communities, particularly fishermen and fish farmers are very difficult to obtain capital. The seasonal nature of fisheries business, uncertainty and high risk is often the reason for the reluctance of the bank provide capital for these businesses. The nature of this kind of fishery business which carries with it the status of fishermen who are generally low and not able to economically make them difficult to satisfy banking terms that should be put in place such as the need for collateral, insurance and equity.

\section{Access to Technology}

Technology used by coastal communities, particularly fishermen, are still at large. Because it's so low productivity and low income eventually. Efforts increase revenue made through technological improvements, ranging from production to postproduction technology and marketing.

Efforts to increase access of society against the technology haven't been much done. This is due to the difficulty to identify the type and the type of technology that it takes a community. Often, instead of more advanced Community in finding the desired technology and adopt. So sometimes the Government left behind. In other words, in terms of the community's more advanced technology from the Government.

\section{Access to the market}

The market is a factor in towing and could become major obstacles when the market is not growing. Because it then open up market access is the way to develop a business because when there is no market then the effort very hampered its development. To develop a market for the resulting products coastal communities then the efforts made are approaching communities with large companies that also are commodity exporters of fisheries. For it then the product sales contract between fishing communities with this company. The advantage of such a relationship, namely the community got a 
guarantee of market and price, construction on the community especially in terms of quality of goods can be carried out, as well as the community gets too often help capital for business development.

\section{E. The development of collective action}

Empowerment through the development of collective action are the same meaning with the development of a cooperative or a joint venture group. Only here the term used is collective action that is to open up opportunities to communities forming groups that it wants that is not solely a co-operative or joint venture group.

\section{CONCLUSION}

Many potential marine resources scattered waters Indonesia, but surely we haven't been able to understand the value of its ecological and economic expediency. Actually the economic potential that can be produced and donated for the construction of the nation's very extraordinary magnitude. However, Indonesia's inability to understand the potential of marine resources to manage much less directly related to the level of mastery of marine technology that has not been developed in Indonesia. With the potential-potential that hasn't been export, then role of the educated community will be indispensable in order to seek out and exploit the potentialpotential that has not been well managed. Community-based marine resource management and knowledge of this technology is not something new for the people of Indonesia. Since long ago, local communities in Indonesia have a mechanism and rules work as of the rules of life in society in managing natural resources, including marine resources.

\section{BIBLIOGRAPHY}

[1]. Alicia h. Munnell (1992), "Policy Watch Infrastructure Investment and Economic Growth", Journal of Economic Perspectives-Volume 6, Number 4-Fall 1992.

[2]. Gary w. Evans (2004), "The Environment of Childhood Poverty", American Psychologist, vol. 59, no. 2, 77 - 92.

[3]. Hadi Sasana (2011), "Determinants Analysis in Regional Shopping District/City West Java Province In the Era of Autonomy and Fiscal Decentralization", Journal of business and Economics (JBE), March 2011. $4658-$ vol. 18, no. 1 ISSN: 1412-3126.

[4]. J. Edward Taylor and Thomas Reardon (1996), "Agroclimatic Shock, Income Inequality, and Poverty: Evidence from Burkina Faso," World Development, vol. 24 , no. 5 .

[5]. Martin Ravallion (1995). "Growth and poverty: Evidence for developing countries in the 1980s", Economics Letters 48 (1995) 411-417.

[6]. Martin Ravallion (1997), "Can the developing highinequality countries escape absolute poverty?", Economics Letters, vol. 56 (1997): 51-57.

[7]. Purbayu and Retno (2005), "an analysis of the Original Regional Revenue (PAD) and the factors that affected him in the effort of implementing Regional Autonomy in
ISSN No:-2456-2165

Kediri Regency," dynamics of Development vol. 2 No. $1 / 2005$ lull.

[8]. Rofiuddin (2012), "analysis of financial performance Area on the island of Madura, East Java province in the autonomous region of the year 2005-2009", publication of the manuscript.

[9]. Susy Susilawati (2007), "public policy analysis of the field of Work safety and health in the town of Tasikmalaya," Thesis, master of public health Science University of Diponegoro in Semarang 2007.

[10]. Yuli dkk (2012), "public policy that is Participatory and communicative", Journal of public policy, Volume 3, number 2, October 2012, pp. 59-141.

[11]. Nonymous. 2012. the key Paper at a National Seminar on Maritime VIII. Surabaya: University Of Hang Tuah Arimoto, t. 2002. Arimoto, t. 2001. Technical Approach to Minimize Fishing Impacts Toward Sustainable Fisheries. in Solving By-catch: Considerations for Today and Tomorrow. Published by the University of Alaska. $\mathrm{P}$ 13-28. Article in Magazine Innovation (XVIII/2006).

[12]. The BRKP, 2004. Support of research and the science and technology of marine and fisheries in execution Jakarta: gate of Mina Bahar Dahuri-R, j. Rais, s. p. Ginting, m. j. Sitepu. 1996. The coastal and ocean resource management Are Integrated. Pt. Pradnya Paratima. Jakarta.

[13]. Ahmad Fauzy, Anna Suzy, 2005. Modeling of Fisheries and Marine Resources, for the analysis of policies. Gramedia. Jakarta.

[14]. Susilowati, beautiful. 2013. Harmony in the utilization and management of Fishery Resources for humans and the environment. Platax scientific journal vol. I-II, January 2013. Diponegoro University Press, London.

[15]. RI-laws No. 27 Year 2007 about management of the coastal areas and small islands.

[16]. Arsyad, r., 2012, Marine or Maritime?, shnews.co, Wednesday, June 13, 2012.

[17]. Atmadja, m., 1996, Indonesia Existence as an archipelago, delivered the warning During a gathering at the Makassar Serui (SSMS96) in Ujung Pandang, July 30, 1996, in order to commemorate the 50 years of the seventh National Movement figures disposal Makassar to Yapen, Serui, Irian Jaya Dahuri, r., 2013, Maritime Country Revive Momentum, newspaper Sindo, Friday, December 13, 2013.

[18]. Marine Board of Indonesia, are United, SO 2011 By Realizing an independent Indonesia Maritime Countries, go ahead, just and prosperous, the Ministry of maritime and fishery, Jakarta.

[19]. The Ministry of marine and fisheries, 2012, economic policy Economic Model with Blue Marine, Jakarta.

[20]. Compass, 2011, change insights, Marine Building, issue 8 February 2011, Jakarta.

[21]. Compass, 2011, Indonesia has not been able to So State maritime, edition of February 9, 2011, Jakarta.

[22]. Ambo Tuwo, H.. 2011. Management of Coastal and marine Ecotourism. Surabaya International: Brilliant. 